\title{
Faktor Risiko Kejadian Pre Eklampsi Di Kota Cirebon Tahun 2019
}

\author{
Lisnawati ${ }^{1}$, Widiyanti Rani ${ }^{2}$ \\ ${ }^{1}$ Poltekkes Kemenkes Tasikmalaya \\ ${ }^{2}$ Program Studi Kebidanan Cirebon \\ * correspondence author: Handphone: 081263747809,E-mail: Srilina46@gmail.com
}

DOI: $\underline{10.33859 / \mathrm{dksm} . v 11 \mathrm{i1} .566}$

\begin{abstract}
Abstrak
Latar Belakang: Penyebab preeklampsia tidak hanya disebabkan oleh satu faktor saja, melainkan banyak faktor yang menyebabkan penyakit preeklampsi dan eklampsi (multiple causation). Umur, Gravida, Riwayat Preeklampsi, status sosial ekonomi, Diabetes Mellitus, mola hidatidosa, kehamilan ganda, hidrops fetalis, umur $<20$ atau $>35$ tahun, dan obesitas (Indeks Massa Tubuh/IMT). merupakan faktor predisposisi terjadinya preeklampsi (Ulfah, 2013). Dengan demikian, apabila salah satu faktor tadi ada pada ibu hamil maka ibu hamil tersebut dapat mempunyai kerentanan untuk mengalami pre eklampsi dalam kehamilannya. Terkadang ibu hamil tidak sadar dengan keadaan dirinya yang sudah menderita preeklampsi.

Tujuan: mengetahui faktor risiko kejadian preeklampsi di kota Cirebon tahun 2019

Metode: Peneltian analitik dengan pendekatan case (ibu hamil pre eklampsi) dan control (ibu hamil normal), untuk mengetahui faktor risiko (umur, gravida, riwayat pre eklampsi, indeks massa tubuh (IMT) dan konsumsi makanan). Penggunaan sampel menggunakan teknik accidental sampling, yaitu memilih 5 Puskesmas dari 22 Puskesmas di wilayah Kota Cirebon yang memiliki kasus pre eklampsi terbanyak, ditambah dengan mengambil kasus di Rumah Sakit Daerah Gunung Jati kota Cirebon. Jumlah sampel 50 orang ibu hamil, yaitu 25 ibu hamil dengan pre eklampsi dan 25 orang ibu hamil normal. Analisis bivariat dengan chi square.

Hasil: Tidak terdapat hubungan antara umur ibu dengan kejadian pre eklampsi, dengan $p$ value 0,667. Tidak terdapat hubungan antara jumlah kehamilan (gravida) dengan kejadian pre eklampsi, dengan $p$ value 1,00. Tidak terdapat hubungan antara riwayat pre eklampsi dengan kejadian pre eklampsi, dengan $p$ value 0,49 . Tidak terdapat hubungan antara IMT dengan kejadian pre eklampsi, dengan $p$ value 0,463 . Tidak terdapat hubungan antara konsumsi makanan dengan kejadian pre eklampsi, dengan $p$ value 1,00. Tidak terdapat hubungan antara kecemasan antenatal dengan kejadian pre eklampsi, dengan $p$ value 0,098 .

Simpulan: Tidak ada hubungan antara umur, gravida, riwayat pre eklampsi, IMT dan konsumsi makanan dengan kejadian pre eklampsia. Penyebab Pre eklampsi yang masih belum pasti sampai saat ini, sehingga berbagai upaya diharapkan bisa dilakukan untuk mengurangi faktor risiko ibu pada kehamilan.

Kata Kunci: umur, gravida, riwayat pre eklampsi, IMT, konsumsi makanan, kecemasan, pre eklampsi
\end{abstract}




\section{Abstract}

Background: The cause of preeclampsia is not only caused by one factor, but many factors that cause preeclampsia and eclampsia (multiple causation). Age, Gravida, Preeclampsia History, socioeconomic status, Diabetes Mellitus, hydatidiform mole, multiple pregnancy, fetal hydrops, age $<20$ or $>35$ years, and obesity (Body Mass Index / BMI). is a predisposing factor to the occurrence of preeclampsia (Ulfah, 2013). Thus, if one of these factors is present in a pregnant woman, the pregnant woman can have the susceptibility to experiencing preeclampsia in her pregnancy. Sometimes pregnant women are unaware of their preeclampsia.

Objective: to determine the risk factors for preeclampsia in the city of Cirebon in 2019

Method: Analytical research with case approach (preeclampsia pregnant women) and control (normal pregnant women), to determine risk factors (age, gravida, history of preeclampsia, body mass index (BMI) and food consumption). The use of samples using accidental sampling technique, which is choosing 5 Puskesmas out of 22 Puskesmas in the Cirebon City area that has the most preeclampsia cases, plus taking a case at the Gunung Jati Regional Hospital in Cirebon. The number of samples was 50 pregnant women, namely 25 pregnant women with preeclampsia and 25 normal pregnant women. Bivariate analysis with chi square.

Results: There was no relationship between maternal age and preeclampsia, with a p value of 0.667. There is no relationship between the number of pregnancies (gravida) with the incidence of preeclampsia, with a $p$ value of 1.00. There is no relationship between preeclampsia history and preeclampsia events, with a $p$ value of 0.49 . There is no relationship between BMI with preeclampsia events, with $p$ value 0.463 . There is no relationship between food consumption and preeclampsia, with a $p$ value of 1.00. There was no relationship between antenatal anxiety with preeclampsia, with a $p$ value of 0.098 .

Conclusion: There is no relationship between age, gravida, history of pre-eclampsia, BMI and food consumption with the incidence of pre-eclampsia. The causes of preeclampsia are still uncertain at this time, so various efforts are expected to be made to reduce maternal risk factors in pregnancy.

Keywords: age, gravida, history of pre-eclampsia, BMI, food consumption, anxiety, pre-eclampsia

\section{Pendahuluan}

Berdasarkan data Survey Demografi Kesehatan Indonesia (SDKI) tahun 2015, menunjukkan bahwa Angka Kematian Ibu (AKI) di Indonesia adalah 305/100.000 Kelahiran Hidup. Berdasarkan laporan World Bank tahun 2017, dalam sehari ada empat ibu di Indonesia yang meninggal akibat melahirkan, dengan kata lain, ada satu ibu yang meninggal setiap enam jam. Angka ini menempatkan Indonesia dengan AKI tertinggi kedua di Asia Tenggara. Urutan pertama adalah Negara Laos dengan 359/100.000 KH. Bila dibandingkan dengan tetangga terdekat, yaitu Singapura dan Malaysia, AKI di Indonesia masih sangat besar. Negara Singapura, AKI pada tahun 2015 adalah 7/100.000 KH, sedangkan Malaysia adalah 24/100.000 KH. (WHO, 2015).

Pre eklampsi termasuk dalam salah satu penyebab utama kematian ibu dan bayi di dunia. Setiap tahun nya, terdapat 76.000 wanita meninggal dan 500.000 kematian bayi akibat pre eklampsi. Di Amerika Serikat, Kanada dan Eropa Barat 2-5\%. Angka kejadian pre 
eklampsi dan eklampsi di kawasan Afrika mencapai 4-18 \%. Pre eklampsi menjadi penyebab utama kematian Ibu di negara Amerika Serikat. Menurut WHO tahun 2015, penyebab kematian ibu yang paling umum di Indonesia yaitu perdarahan 28\%, pre eklampsi/eklampsi 24\% dan infeksi 11\%.

Penyebab preeklampsia tidak hanya disebabkan oleh satu faktor saja, melainkan banyak faktor yang menyebabkan penyakit preeklampsi dan eklampsi (multiple causation). Riwayat Preeklampsi, status sosial ekonomi, paritas, Diabetes Mellitus, mola hidatidosa, kehamilan ganda, hidrops fetalis, umur lebih dari 35 tahun dan obesitas (Indeks Massa Tubuh/IMT). merupakan faktor predisposisi terjadinya preeklampsi (Ulfah, 2013). Dengan demikian, apabila salah satu faktor tadi ada pada ibu hamil maka ibu hamil tersebut dapat mempunyai kerentanan untuk mengalami pre eklampsi dalam kehamilannya. Terkadang ibu hamil tidak sadar dengan keadaan dirinya yang sudah menderita preeklampsi.

Pengendalian preeklampsi selama kehamilan dapat dilakukan dengan perawatan di Rumah Sakit atau di rumah, istirahat, pengobatan hipertensi, serta pengawasan ibu dan janin. Preeklampsi juga dapat dikendalikan dengan diet yang teratur, relaksasi managemen stress yang baik, identifikasi dan pengobatan dini, monitor tekanan darah teratur, tes urine dan gaya hidup sehat. (Raddi \& Kardhe, 2010)

Berdasarkan survey pendahuluan yang dilakukan pada beberapa Puskesmas yang ada di Kota Cirebon, angka kejadian pre eklampsi setiap tahunnya selalu ada. Dari 5 (lima) Puskesmas (Majasem, Nelayan, Larangan, Gunung Sari dan Pekalangan) didapatkan bahwa rata-rata kejadian pre eklampsi pada tahun 2018 adalah 10-20 kasus di tiap Puskesmas.

Menurut Chobanian (2014), pre eklampsi merupakan salah satu konsekuensi gaya hidup tidak sehat pada ibu hamil. Modifikasi gaya hidup merupakan salah satu promosi kesehatan yang bertujuan untuk mencegah terjadinya kasus peningkatan tekanan darah dan penyakit kardiovaskular. Modifikasi gaya hidup pada ibu hamil meliputi pengaturan pola makan dengan diet jenis makanan kaya buah, sayur, protein, produk rendah karbohidrat dan lemak, serta melakukan aktivitas fisik ringan secara teratur minimal lima belas sampai tiga puluh menit per hari seperti jalan santai dan senam.

Kurki, et al (2010) melaporkan depresi dan kecemasan antenatal terkait dengan eksresi vasoaktif hormon atau neuroendokrin lainnya, yang pada gilirannya meningkatkan risiko hipertensi, hal ini juga memicu perubahan pembuluh darah dan peningkatan resistensi arteri uterina yang sama halnya terjadi pada kasus pre eklampsi.

\section{Metode}

Sebelum dilakukan pengambilan data, terlebih dahulu peneliti melakukan uji validitas dan reliabilitas pada kuesioner tentang 
kecemasan antenatal yang akan digunakan. Responden untuk uji validitas dan reliabilitas, diiambil dari ibu hamil trimester III yang ada pada Puskesmas Kalitanjung sebanyak 15 orang. Hasil yang didapat nilai Cronbach's alpha 0,942 dari 28 pertanyaan

Pengambilan data dilakukan dengan terlebih dahulu mengambil data kasus pre eklampsi yang ada di Kota Cirebon. Pada penelitian ini, sampel yang diambil adalah ibu yang terdiagnosis pre eklampsi hanya pada saat hamil, dan tidak memasukan data pada ibu yang terdiagnosis pre eklampsi pada awitan persalinan. Pengumpulan data umtuk kasus pre eklampsi, peneliti dapat dari 5 lokasi yang berbeda, yaitu : Puskesmas Kalitanjung, Pegambiran, Majasem, Larangan di tambah dengan kasus yang ada di RS Daerah Gunung Jati Cirebon.

Teknik pengambilan sampel secara accidental sampling, peneliti mendapatkan 25 kasus pre eklampsi (Puskesmas Kalitanjung 10 orang, Pegambiran 7 orang, Majasem 4 orang, Larangan 2 orang, RSD Gunung Jati 2 orang). Berdasarkan jumlah kasus yang didapat, peneliti mengambil data untuk kelompok kontrol dengan perbandingan 1:1, sehingga peneliti mengambil 25 orang ibu hamil normal dengan usia kehamilan di trimester III, dengan lokasi pengambilan data di wilayah kerja Puskesmas Kalitanjung Kota Cirebon.

\section{Hasil}

\section{a. Umur}

Tabel 1 Distribusi Frekuensi Berdasarkan Umur

\begin{tabular}{lll}
\hline Umur & Frekuensi & $\begin{array}{l}\text { Persen } \\
(\%)\end{array}$ \\
\hline tidak berisiko & 40 & 80 \\
\hline berisiko & 10 & 20 \\
\hline Total & 50 & 100 \\
\hline
\end{tabular}

Berdasarkan tabel di atas, sebagian besar umur ibu adalah tidak berisiko yaitu sebanyak 40 orang atau $80 \%$.

Tabel 2.Hubungan umur ibu dengan kejadian pre eklampsi

\begin{tabular}{|c|c|c|c|c|}
\hline Umur Ibu & $\begin{array}{l}\text { Tidak } \\
\text { pre } \\
\text { eklam } \\
\text { psi }\end{array}$ & $\begin{array}{l}\text { Pre } \\
\text { Eklam } \\
\text { psi }\end{array}$ & Total & $\begin{array}{l}p \text { value } \\
\text { (Fisher } \\
\text { exact) }\end{array}$ \\
\hline \multirow{2}{*}{$\begin{array}{l}\text { Tidak } \\
\text { berisiko }\end{array}$} & 21 & 23 & 44 & \multirow{7}{*}{0,667} \\
\hline & $84 \%$ & $92 \%$ & $88 \%$ & \\
\hline \multirow[t]{2}{*}{ Berisiko } & 4 & 2 & 6 & \\
\hline & $16 \%$ & $8 \%$ & $12 \%$ & \\
\hline \multirow[t]{3}{*}{ Total } & 25 & 25 & 50 & \\
\hline & 100 & $100 \%$ & 100 & \\
\hline & $\%$ & & $\%$ & \\
\hline
\end{tabular}

Berdasarkan tabel 2, didapatkan nilai $p$ value adalah 0,667 sehingga umur ibu tidak berhubungan dengan kejadian pre eklampsi.

\section{b. Gravida}

Tabel 3 Distribusi Frekuensi berdasarkan jumlah kehamilan (gravida)

\begin{tabular}{lcc}
\hline \multicolumn{1}{c}{ Gravida } & Frekuensi & $\begin{array}{c}\text { Persen } \\
\mathbf{( \% )}\end{array}$ \\
\hline tidak berisiko & 40 & 80 \\
\hline berisiko & 10 & 20 \\
\hline Total & 50 & 100 \\
\hline
\end{tabular}

Berdasarkan tabel 3, diketahui bahwa sebagian besar jumlah kehamilan ibu adalah tidak berisiko yaitu sebanyak 40 orang atau $80 \%$. 
Tabel 4 Hubungan gravida dengan kejadian pre eklampsi

\begin{tabular}{ccccc}
\hline Gravida & $\begin{array}{c}\text { Tidak } \\
\text { pre } \\
\text { eklampsi }\end{array}$ & $\begin{array}{c}\text { Pre } \\
\text { Ekla } \\
\text { mpsi }\end{array}$ & Total & $\begin{array}{c}\text { p value } \\
\text { (Ass. } \\
\text { Sig) }\end{array}$ \\
\hline Tidak & 20 & 20 & 40 & \\
berisiko & $80,0 \%$ & $\begin{array}{c}80,0 \\
\%\end{array}$ & $80 \%$ & \\
\hline Berisiko & 5 & 5 & 10 & \multirow{2}{*}{1,00} \\
\cline { 2 - 4 } & $20,0 \%$ & $\begin{array}{c}20,0 \\
\%\end{array}$ & $20 \%$ & \\
\hline Total & 25 & 25 & 50 & \\
\cline { 2 - 4 } & $100 \%$ & $\begin{array}{c}100 \\
\%\end{array}$ & $100 \%$ & \\
\hline
\end{tabular}

Berdasarkan tabel 4 diketahui bahwa nilai $\mathrm{p}$ value adalah 1,00 , sehingga jumlah kehamilan tidak berpengaruh dengan kejadian pre eklampsi.

\section{c. Riwayat Hipertensi}

Tabel 5 Frekuensi berdasarkan Riwayat pre eklampsi

\begin{tabular}{lcc}
\hline $\begin{array}{c}\text { Riwayat } \\
\text { Hipertensi }\end{array}$ & Frekuensi & Persen (\%) \\
\hline $\begin{array}{l}\text { tidak } \\
\text { berisiko }\end{array}$ & 48 & 96 \\
\hline berisiko & 2 & 4 \\
\hline Total & 50 & 100 \\
\hline
\end{tabular}

Berdasarkan tabel 5, diketahui bahwa sebagian besar sampel tidak memiliki riwayat pre eklampsi pada kehamilan sebelumnya yaitu sebanyak 48 orang atau $96 \%$.

Tabel 6 Hubungan Riwayat Pre eklampsi dengan kejadian pre eklampsi

\begin{tabular}{|c|c|c|c|c|}
\hline $\begin{array}{c}\text { Riwayat } \\
\text { Hiperte } \\
\text { nsi }\end{array}$ & $\begin{array}{c}\text { Tidak } \\
\text { pre } \\
\text { eklam } \\
\text { psi }\end{array}$ & $\begin{array}{c}\text { Pre } \\
\text { Eklam } \\
\text { psi }\end{array}$ & Total & $\begin{array}{c}p \\
\text { value } \\
\text { (Fish } \\
\text { er } \\
\text { exact } \\
\quad)\end{array}$ \\
\hline \multirow{2}{*}{$\begin{array}{c}\text { Tidak } \\
\text { berisiko }\end{array}$} & 25 & 23 & 48 & \multirow{6}{*}{0,490} \\
\hline & $\begin{array}{c}100,0 \\
\%\end{array}$ & $92,0 \%$ & $\begin{array}{c}96,0 \\
\%\end{array}$ & \\
\hline \multirow[t]{2}{*}{ Berisiko } & 0 & 2 & 2 & \\
\hline &, $0 \%$ & $8,0 \%$ & $4,0 \%$ & \\
\hline \multirow[t]{2}{*}{ Total } & 25 & 25 & 50 & \\
\hline & $\begin{array}{c}100,0 \\
\%\end{array}$ & $\begin{array}{c}100,0 \\
\%\end{array}$ & $\begin{array}{c}100,0 \\
\%\end{array}$ & \\
\hline
\end{tabular}

Berdasarkan tabel 7, dapat diketahui bahwa nilai $p$ value adalah 0,490 , sehinggan riwayat pre eklampsi tidak berhubungan dengan kejadian pre eklampsi.

\section{d. Indeks Massa Tubuh (IMT)}

Tabel 7 Distribusi Frekuensi berdasarkan IMT e.

\begin{tabular}{lcc}
\multicolumn{1}{c}{ IMT } & Frekuensi & Persen (\%) \\
\hline $\begin{array}{l}\text { tidak } \\
\text { berisiko }\end{array}$ & 9 & 18 \\
\hline berisiko & 41 & \\
\hline Total & 50 & 100 \\
\hline
\end{tabular}

Berdasarkan tabel 7, diketahui bahwa sebagian besar sampel termasuk dalam kelompok IMT berisiko sebanyak 41 orang atau $82 \%$.

Tabel 8 Hubungan IMT dengan kejadian pre eklampsi

\begin{tabular}{|c|c|c|c|c|}
\hline IMT & $\begin{array}{c}\text { Tidak } \\
\text { pre } \\
\text { eklampsi }\end{array}$ & $\begin{array}{c}\text { Pre } \\
\text { Eklampsi }\end{array}$ & Total & $\begin{array}{c}p \\
\text { value } \\
\text { (exac } \\
\text { t sig) }\end{array}$ \\
\hline \multirow{2}{*}{$\begin{array}{c}\text { Tidak } \\
\text { berisik } \\
\text { o }\end{array}$} & 6 & 3 & 9 & \multirow{6}{*}{0,463} \\
\hline & $24 \%$ & $12 \%$ & $18 \%$ & \\
\hline \multirow{2}{*}{$\begin{array}{c}\text { Berisik } \\
\mathrm{o}\end{array}$} & 19 & 22 & 41 & \\
\hline & $76 \%$ & $88 \%$ & $82 \%$ & \\
\hline \multirow[t]{2}{*}{ Total } & 25 & 25 & 50 & \\
\hline & $100 \%$ & $100 \%$ & $\begin{array}{c}100 \\
\%\end{array}$ & \\
\hline
\end{tabular}

Berdasarkan tabel 8, dapat diketahui bahwa nilai $p$ value adalah 0,463, sehinggan riwayat IMT tidak berhubungan dengan kejadian pre eklampsi. 


\section{e. Konsumsi makanan}

Tabel 9 Distribusi Frekuensi berdasarkan Konsumsi makanan

\begin{tabular}{lcc}
\hline $\begin{array}{c}\text { Konsumsi } \\
\text { makanan }\end{array}$ & Frekuensi & Persen (\%) \\
\hline tidak berisiko & 7 & 14 \\
\hline berisiko & 43 & 86 \\
\hline Total & 50 & 100 \\
\hline
\end{tabular}

Berdasarkan tabel 9, diketahui bahwa sebagian besar sampel termasuk dalam kelompok berisiko sebanyak 43 orang atau $86 \%$.

Tabel 10 Hubungan Konsumsi makanan dengan kejadian pre eklampsi

\begin{tabular}{cclcc}
\hline $\begin{array}{c}\text { Konsumsi } \\
\text { makanan }\end{array}$ & $\begin{array}{c}\text { Tidak } \\
\text { pre } \\
\text { eklampsi }\end{array}$ & $\begin{array}{l}\text { Pre } \\
\text { Eklam }\end{array}$ & Total & $\begin{array}{c}\text { p value } \\
\text { (fisher } \\
\text { exact) }\end{array}$
\end{tabular}

\begin{tabular}{cccc}
\hline Tidak & 3 & 4 & 7 \\
berisiko & $12 \%$ & $16 \%$ & $14 \%$ \\
\hline Berisiko & 22 & 21 & 43 \\
\cline { 2 - 4 } & $88 \%$ & $84 \%$ & $86 \%$ \\
\hline Total & 25 & 25 & 50 \\
\cline { 2 - 4 } & $100 \%$ & $100 \%$ & 100 \\
& & & $\%$ \\
\hline
\end{tabular}

Berdasarkan tabel 11, dapat diketahui bahwa nilai $p$ value adalah 1,00, sehinggan Konsumsi makanan tidak berhubungan dengan kejadian pre eklampsi.

\section{f. Kecemasan antenatal}

Tabel 12 Distribusi Frekuensi berdasarkan Kecemasan antenatal

\begin{tabular}{lcc}
\hline $\begin{array}{c}\text { Kecemasan } \\
\text { antenatal }\end{array}$ & Frekuensi & $\begin{array}{c}\text { Persen } \\
(\mathbf{\%})\end{array}$ \\
\hline tidak berisiko & 12 & 24 \\
\hline berisiko & 38 & 76 \\
\hline Total & 50 & 100 \\
\hline
\end{tabular}

Berdasarkan tabel 10, diketahui bahwa sebagian besar sampel termasuk dalam kelompok berisiko sebanyak 43 orang atau $86 \%$.

Tabel 13 Hubungan Kecemasan antenatal dengan kejadian pre eklampsi

\begin{tabular}{ccccc}
\hline $\begin{array}{c}\text { Konsu } \\
\text { msi } \\
\text { makan } \\
\text { an }\end{array}$ & $\begin{array}{c}\text { Tidak } \\
\text { pre } \\
\text { eklam } \\
\text { psi }\end{array}$ & $\begin{array}{c}\text { Pre } \\
\text { Eklam } \\
\text { psi }\end{array}$ & $\begin{array}{c}\text { Tota } \\
\mathbf{l}\end{array}$ & $\begin{array}{c}\text { p value } \\
\text { (Contin } \\
\text { uity } \\
\text { Correcti } \\
\text { on) }\end{array}$ \\
\hline $\begin{array}{c}\text { Tidak } \\
\text { berisiko }\end{array}$ & 9 & 3 & 12 & \\
\cline { 2 - 4 } & $36 \%$ & $12 \%$ & $\begin{array}{c}24 \\
\%\end{array}$ & \\
\hline Berisik & 16 & 22 & 38 \\
o & $64 \%$ & $88 \%$ & 76 & \multirow{2}{*}{0,098} \\
& & & $\begin{array}{c}0 \\
\%\end{array}$ & \\
\cline { 2 - 4 } Total & 25 & 25 & 50 & \\
\cline { 2 - 4 } & $100 \%$ & $100 \%$ & $\begin{array}{c}100 \\
\%\end{array}$ & \\
\hline
\end{tabular}

Berdasarkan tabel 13, dapat diketahui bahwa nilai $p$ value adalah 0,098 , sehinggan Kecemasan antenatal tidak berhubungan dengan kejadian pre eklampsi.

\section{Pembahasan}

\section{Umur Ibu Dengan Kejadain Pre eklampsi}

Sebagian besar responden ada pada umur yang tidak berisiko yaitu umur 2035 tahun, yaitu pada rentang umur ini merupakan umur yang aman dari risiko timbulnya penyulit dalam kehamilan (Saifuddin, 2010). Hasil analisis bivariat menunjukkan bahwa nilai $\mathrm{p}=0,667$. Hal ini menunjukkan bahwa umur ibu tidak berhubungan dengan kejadian pre eklampsi. Maknanya, kejadian pre 
eklampsi dapat terjadi pada berbagai umur ibu. Pada penelitian ini, kejadian pre eklampsi paling banyak terdapat pada kelompok tidak berisiko.

Hasil ini sejalan dengan penelitian Wuryandari bahwa frekuensi kejadian pre eklampsi terbanyak pada kelompok umur 20-35 tahun. Namun, tidak sejalan dengan pendapat Robson, dkk. Bahwa ibu hamil dengan umur $<20$ dan $>35$ merupakan faktor risiko kejadian pre eklampsi selain penyakit vaskuler, ginjal, diabetes mellitus, hipertensi kronis dan penyakit lainnya. Didukung dengan temuan Abalos et al, bahwa ada hubungan yang signifikan antara usia ibu $>35$ tahun dengan kejadian pre eklampsi. Peneliti yang sama juga mengatakan bahwa remaja usia $<19$ tahun tidak berhubungan dengan kejadian pre eklampsi, tetapi memiliki risiko kejadian pre eklampsi.

Dari pernyataan tersebut dapat disimpulkan bahwa pengelompokkan usia merupakan salah satu faktor penting dalam program kesehatan ibu dan anak di indonesia. Tidak menutup kemungkinan bahwa pre eklampsi dapat terjadi pada umur ibu yang tidak berisiko (20-35). Sehingga semua ibu hamil baik pada umur tang berisiko maupun tidak berisiko wajib dilakukan pemantauan kehamilan yang intensif agar dapat meminimalkan faktor risiko yang terjadi melalui kunjungan Ante Natal Care (ANC) yang teratur.

\section{Gravida dengan Kejadian Pre eklampsia}

Penelitian Tita tahun 2012 tentang Hubungan antara gaya hidup semasa kehamilan dengan kejadian pre eklampsi, menunjukkan bahwa umur $(\mathrm{p}=0.000, \mathrm{OR}$ $=11.21)$ dan konsumsi makanan $(\mathrm{p}=$ $0,028$, OR $=471)$ berhubungan dengan kejadian pre eklampsi.

Jumlah kehamila (gravida) pada hasil penelitian ini menunjukkan bahwa tidak terdapat hubungan antara jumlah kehamilan dengan kejadian pre eklampsi, dengan nilai $p=1,00$. Hasil penelitian ini sejalan dengan penelitian di RSUD Kardinah Kota Tegal menemukan tidak ada hubungan yang bermakna antara paritas dengan kejadian pre eklampsi (Indriani, 2012).

Hasil penelitian ini tidak sejalan dengan penelitian di RSU Bahtera mas Sulawesi Tenggara menunjukkan bahwa gravida merupakan faktor risiko kejadian pre eklampsi dengan OR 2,881 yang berarti ibu hamil dengan paritas 1 kali atau primigravida memiliki risiko 2,881 kali terjadi pre eklampsi dibandingkan dengan ibu hamil dengan status multigravida (Afridasari, 2013)

Risiko pre eklampsi pada kehamilan pertama 4,1\%, dibandingkan dengan kehamilan kedua sebesar 1,7\%, dan kehamilan ketiga sebesar $1,8 \%$. Hal ini membuktikan bahwa persalinan kedua dan 
ketiga merupakan persalinan yang aman dari pre eklampsi (Diaz, 2009)

Tidak adanya hubungan antara gravida dengan kejadian pre eklampsi pada penelitian ini kemungkinan disebabkan karena sampel berada pada kategori multipara

\section{Riwayat Hipertensi dengan Kejadian}

\section{Pre eklampsi}

Hasil analisis bivariat riwayat hipertensi dengan kejadian pre eklampsi menunjukkan bahwa tidak ada hubungan antara riwayat hipertensi dengan kejadia pre eklampsi (nilai $\mathrm{p}=0,490$ ). Hasil penelitian ini sejalan dengan penelitian Tigor (2016) tentang Faktor yang berhubungan dengan kejadian pre eklampsi pada ibu hamil di Poli KIA RSU Anutapura Palu, menunjukkan bahwa riwayat hipertensi tidak berhubungan dengan pre eklampsi (nilai $\mathrm{p}=0,060$ ).

Hasil penelitian ini tidak sejalan dengan penelitian Novi tahun 2016 tentang Determinan gangguan hipertensi kehamilan di Indonesia, yang menunjukkan bahwa hipertensi kronik berhubungan degan gangguan hipertensi dalam kehamilan dengan RP : 2,13 (95\% CI 1,80-2,51). Begitu pula pada penelititian yang dilakukan oleh Istiana, dkk (2017) menunjukkan bahwa riwayat pre eklampsi berisiko terjadianya pre eklampsi dengan nilai Nilai $\mathrm{OR}=5,950$ (CI: 1,586-22,328), artinya ibu hamil yang memiliki riwayat hipertensi memiliki peluang 5,9 kali untuk terjadi pre eklampsi dibandingkan ibu hamil yang tidak memiliki riwayat pre eklampsi.

\section{IMT dengan Kejadian pre eklampsi}

Indeks Massa Tubuh (IMT) tidak berhubungan dengan kejadian pre eklampsi (nulai $\mathrm{p}=0,463$ ). Hasil ini tidak sejalan dengan penelitian yang dilakukan di RSUP DR. M. Djamil Padang menunjukkan bahwa terdapat hubungan yang signifikan antara obesitas dengan kejadian pre eklampsi $\quad(p=0,031$, $\mathrm{OR}=4,060$ ), yang beararti ibu hamil yang obesitas berisiko 4,060 kali terkena pre eklampsi dibandingkan dengan ibu hamil yang tidak obesitas. Obesitas adalah faktor risiko untuk pre eklampsi, kondisi ini mungkin terkait dengan adanya stres oksidatif, peradangan dan fungsi vaskular yang berubah. Infiltrasi vaskular neutrofil dan peradangan vaskular yang ekstensif telah dilaporkan pada ibu hamil pre eklampsi dan wanita gemuk. (Dien Gusta, dkk. 2014)

Kegemukan dikaitkan dengan peradangan tingkat rendah dan peningkatan sirkulasi inflamasi Kadar protein $\mathrm{C}$ - reaktif plasma, TNF $-\alpha$, IL-6 dan IL-8 meningkat pada subyek obesitas dan lemak tubuh adalah sumber yang mungkin dari penanda inflamasi ini. Penanda peradangan adalah meningkatnya 
pembuluh darah wanita gemuk dan ini dapat menyebabkan target vaskular dalam prerubahan vaskular yang berhubungan dengan pre eklampsi. Obesitas juga terkait dengan peningkatan sirkulasi tingkat leptin dan polimorfisme gen leptin telah dikaitkan dengan peningaktan risiko pengembangan pre eklampsi.

\section{Konsumsi makanan dengan kejadian pre} eklampsi

Konsumsi makanan ibu hamil tidak berhubungan dengan keadian pre eklampsi (nilai $\mathrm{p}=1$ ). Hasil penelitian ini sejalan dengan penelitian Rudy (2017), tentang hubungan asupan energi dan gizi makro serta status gizi pada pasien pre eklampsi di RSIA Siti Fatimah Kota Makassar, yang menunjukkan bahwa tidak ada hubungan antara asupan energi dengan kejadian pre eklampsi (nilai $\mathrm{p}=0,584$ ), tidak ada hubungan asupan protein dengan kejadian pre eklampsi (nilai $\mathrm{p}=0,611$ ), tidak ada hubungan asupan lemak dengan kejadian pre eklampsi (nilai $\mathrm{p}=0,416$ ), dan tidak ada hubungan asupan karbohidrat dengan kejadian pre ekampsi (nilai $\mathrm{p}=0,649$ ).

$$
\text { Penelitian Fatmawati }
$$
menunjukkan bahwa pola makan tidak berhubungan dengan kejadian pre eklampsi (nilai $\mathrm{p}=0,204)$

Konsumsi buah dan sayur bukan prediktor kejadian pre eklampsi. Gambaran kecukupan konsumsi buah dan sayur menunjukkan bahwa ibu hamil di
Indonesia kemungkinan besar memiliki kesadaran rendah tentang manfaat perilaku pencegahan dan kerentanan penyakit yang dapat ditimbulkan akibat perilaku kesehatan yang buruk, salah satunya dari kebiasaan mengkonsumsi makanan harian.

\section{Kecemasan antenatal dengan kejadian pre eklampsi}

Kecemasan antenatal tidak berhubungan dengan kejadian pre eklampsi (nilai $\mathrm{p}=0,098$ ). Hasil penelitian ini sesuai dengan penelitian Intan (2010) tentang Hubungan antara kecemasan dengan pre eklampsi, dengan hasil tidak ada hubungan dengan nilai $p=0,089$. Hasil penelitian ini tidak sesuai dengan penelitian Adi Isworo (2012) tentang hubungan antara kecemasan dengan kejadian pre eklampsi di kabupaten Banyumas Jawa Tengah, bahwa kecemasan berhubungan dengan kejadian pre eklampsi dengan $\mathrm{OR}=7,84$ (CI : 3,967 $-15,501)$

Ibu hamil hipertensi memiliki kecemasan tinggi dalam menghadapi persalinan dikarenakan risiko yang besar yang akan dihadapi oleh dirinya maupun bayinya yang akan dilahirkan. Kondisi tersebut akan bertambah sulit jika ibu hamil hipertensi memiliki persaan persaan yang mengancam seperti munculnya perasaan khawatir yang berlebihan, kecemasan dalam menghadapi persalinan, ketidakpahaman apa yang akan 
terjadi pada persalinannya. Gejala-gejala tersebut akan mempengaruhi ibu hamil hipertensi baik secara fisik maupun psikis (Sijangga, 2010).

Meskipun di beberapa teori tidak pernah disinggung kitannya dengan kejadian pre eklampsi, namun pada teori kecemasan yang berlangsung dalam waktu yang panjang dapat mengakibatkan gangguan seperti pada tekanan darah. Manifestasi dari kecemasan diantaranya meningkatnya tekanan darah berhubungan dengan kontraksi pembuluh darah reservoar seperti kulit, ginjal dan organ lain. Sekresi urine meningkat sebagai efek dari norepinefrin, retensi air dan garam meningkat akibat produksi mineral kortikoid sebagai akobat meningkatnya volume darah curah jantung meningkat.

\section{Simpulan}

Tidak terdapat hubungan antara umur, gravida, riwayat pre eklampsi, IMT, konsumsi makanan dan kecemasan dengan kejadian pre eklampsi

\section{Saran}

Kejadian pre eklampsi masih merupakan salah satu penyumbang dalam angka kematian ibu dan bayi, dengan penyebab yang masih belum pasti sampai saat ini, sehingga berbagai upaya diharapkan bisa dilakukan untuk mengurangi faktor risiko ibu pada kehamilan.

\section{Ucapan Terima kasih}

Terimakasih yang sebesar-besarnya saya ucapkan kepada PPSDM Kes melalui program ini saya bisa meneliti sebagai peneliti dosen pemula, dan ucapan trimakasih kepada Poltekkes Kemenkes Tasikmalaya, seluruh tim penelitian yang banyak memberikan masukan dan arahan, Dinas Kesehatan Kota Cirebon serta RSUD gunung Jati Kota Cirebon, yang banyak membantu dalam proses penelitian ini dan terakhir kepada semua tim yang membantu sampai kepada penyusunan akhir laporan ini.

\section{Daftar Pustaka}

Adi, dkk. 2012. Hubungan antara Kecemasan dengan kejadian pre eklampsi di Kanupaten Banyumas Jawa Tengah. Berita Kedokteran Masyarakat. Vol.28 No.1, Maret 2012.

Afridasari, 2013. Analisis Faktor Risiko Kejadian Pre eklampsi. FK. UHO

Badan Penelitian dan Pengembangan Kesehatan Kementerian Kesehatan RI. 2013.

Cunningham, F Gary et al, 2013. Obstetri William, alih bahasa Andry Hartono, Jakarta : EGC.

Chobanian AV,2004. Prevention, detection, evaluation and treatment of high blood pressure. 
http://www.njlbi.nih.gov/resources/doc

s/cht-book.htm(sitasi tanggal 5

November 2018.

Depkes RI. 2015. Riset Kesehatan Dasar. Jakarta : Badan penelitian dan Pengembangan Kesehatan Kementerian Kesehatan RI

Diaz SH, 2009. Risk Of Pre eclampsia in first and subsequent Pregnancies : Prospective cohort study. BMJ : 2009 : 2-3

Dien Gusta, dkk. 2014. Faktor Risiko Kejadian Pre eklampsia pada ibu hamil di RSP M. Djamil Padang. Andalas Journal Of Public Health 2015

Dinas Kesehatan Kota Cirebon. Profil Dinas Kesehatan Kota Cirebon Tahun 2018

Djannah SN, 2010. Gambaran epidemiologi kejadian pre eklampsi di RSU PKU Muhamadiya Yogyakarta tahun 20072009. Buletin Penelitian Sistem Kesehatan 2010.

Donsu, J, D, T. 2017. Psikologi Keperawatan Yogyakarta. Pustaka Baru Press. Cetakan I

E.Abalos et al, 2013. Pre eclampsia, Eclampsia and adverser maternal and perinatal outcome : A secondary analysis of the World Health Organization Multicountry Survey on maternal and New Born Health. Original Article

Indriani, 2012. Analisis yang berhubungan dengan faktor-faktor Kejadian pre eklampsi pada ibu bersalin di RSD Kardinah Kota Tegal tahun 2011. Jakarta : Universitas Indonesia

Intan R, 2010. Hubungan antara Kecemasan dengan kejadian Pre eklampsi. Fakultas Kedokteran Universitas Sebelas Maret Surakarta.
Istiana, dkk. 2017. Faktor risiko yang mempengaruhi kejadian hipertensi pada ibu hamil di Wilayah Kerja Puskesmas Kedungmundu Kota semarang tahun 2017. Jurnak Kesehatan Masyarakat ejournal UNDIP, volume 6 nomor 1 , Januari 2018.

Isworo, 2012. Hubungan antara kecemasan dengan kejadian pre eklampsi di Kabupaten Banyumas Jawa Tengah. Berita Kedokateran Masyarakat; vol.28, no:1

Kemenkes RI, 2014. Pedoman Gizi Seimbang. Direktorat Jenderal Bina Gizi dan KIA, Jakarta, hal. 24-26

Kemenkes (2017) Profil Kesehatan Indonesia tahun 2016. Jakarta : Kementerian Kesehatan RI

Kumala Fatma Tiara, 2015. Hubungan antara kejadian pre ekmlapsi dan resiko depresi antenatal di RSI Sunan Kudus. Tesis Universitas Sebelas Maret Surarakarta

Kurki, et al. 2010. Depression and anxiety in early pregnancy and risk for pre eclampsia. The American College of Obstetricians and Gynecologist, Volume 95 issue 4 p 487-490

Novi, dkk. 2016. Determinan gangguan hipertensi dalam kehamilan di Indonesia. Departemen Biostatistik, Universitas Gajah Mada. Berita Kedokteran Masyarakat. Vo. 32 No.9

Panjaitan, 2015. Hubungan Gaya Hidup dengan Kejadian hipertensi di wilayah kerja Puskesmas Helvetia Medan. Skripsi. Hal 22-31

Rozikhan, 2007. Faktor-Faktor Risiko Terjadinya Pre ekllampsi Berat di Rumah Sakit DR. H. Soewondo Kendal, Semarang. Universitas Diponogoro. 
Saifuddin, Abdul mari, 2010. Ilmu Kebidanan. Jakarta, Penerbit : BP-SP

Santi Martini, 2012. Hubungan antara Gaya Hidup Selama Masa Kehamilan dengan Pre eklampsi. The Indonesian Journal of Public Health. Vo.8 No.3 Maret 2012. 122-125

Shodiqoh, Eka R \& Syahrul, Fahriyani. 2014. Perbedaan Tingkat Kecemasan Dalam menghadapi Persalinan Antara Primigravidan dan Multigravida. Fakultas Kesehatan Universitas Airlangga
Tigor, dkk. 2016. Faktor-faktor yang berhubungan dengan kejadian pre eklampsi pada ibu hamil di poli KIA RSU Antapura Palu. Jurnal Kesehatan Tadulako Vo.2 No. 1. 2016

Tita F.P, 2012. Hubungan gaya hidup selama masa kehamilan dan kejadian pre eklampsia. Fakultas Kesehatan Masyarakat Universitas Airlangga, Surabaya. The Indonesian Journal of Public Health, Vol.8, no.3 Maret 2012

Wuryandari, 2012. Faktor-faktor yang berhubungan dengan kejadian pre eklampsia di RSUD Raden Mattaher, Jambi. Online Jurnal 